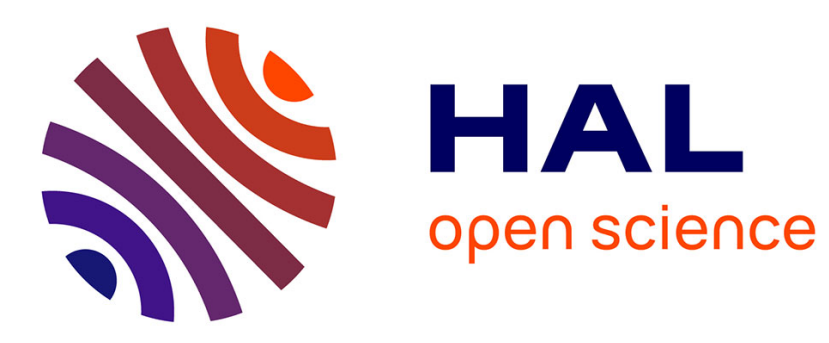

\title{
Factors Influencing Trust in Smart City Services
}

Dmitrii Trutnev, Lyudmila Vidiasova

\section{To cite this version:}

Dmitrii Trutnev, Lyudmila Vidiasova. Factors Influencing Trust in Smart City Services. 18th International Conference on Electronic Government (EGOV), Sep 2019, San Benedetto del Tronto, Italy. pp.353-365, 10.1007/978-3-030-27325-5_27. hal-02445813

\section{HAL Id: hal-02445813 \\ https://hal.inria.fr/hal-02445813}

Submitted on 20 Jan 2020

HAL is a multi-disciplinary open access archive for the deposit and dissemination of scientific research documents, whether they are published or not. The documents may come from teaching and research institutions in France or abroad, or from public or private research centers.
L'archive ouverte pluridisciplinaire HAL, est destinée au dépôt et à la diffusion de documents scientifiques de niveau recherche, publiés ou non, émanant des établissements d'enseignement et de recherche français ou étrangers, des laboratoires publics ou privés. 


\title{
Factors influencing trust in Smart City services
}

\author{
Dmitrii Trutnev ${ }^{(\varpi)[0000-0001-6230-0752]}$ and Lyudmila Vidiasova ${ }^{[0000-0002-8006-7066]}$ \\ ITMO University, 49 Kronverksky pr., Saint Petersburg, 197101, Russia \\ trutnev@egov-center.ru, bershadskaya.lyudmila@gmail.com
}

\begin{abstract}
The introduction of Smart City technologies is aimed at creating various types of public values, including operational, political and social values. One of the basic values created by the Smart City is the increase in trust by its stakeholders. Trust is often considered as one of the most important factors contributing to the success of Smart Cities. The level of trust affects the interactions between actors, which is the basis for the successful development of a Smart City. Interaction is needed the generation of the required public values. Therefore, it is important to know the sources of trust and the degree of their presence in the city turned into a smart one. This paper describes one of the recent studies of trust factors done within the framework of the "Smart St. Petersburg" development project. The findings show that the willingness to participate in the Smart City's strategy development discussion and its development plans co-creation highly depends on the willingness to trust municipal authorities and the familiarity with the Smart City's solutions from around the world.
\end{abstract}

Keywords: Trust, Smart City, e-services.

\section{Introduction}

The active development of Smart Cities and the introduction of information technologies in all spheres of people's lives around the world have raised the question of which factors influences its success. Many researchers agree that mutual trust is one of the main enablers of smart cities benefits; it requires special attention and individual studies $[1,2,3,4]$.

The desire of the government of the Russian Federation and the Administration of St. Petersburg to benefit from digital development has led to the emergence of a number of legislative initiatives. These initiates lay the foundation for further development of the Digital Economy of the Russian Federation [5], and include: The strategy of economic and social development of St. Petersburg for the period up to 2030 [6], the City priority program "Smart St. Petersburg" [7], and the Standard "Smart City" [8]. These and other documents define the goals, strategy and development plans of St. Petersburg as a Smart City. During the first years of implementing a number of factors were not adequately taken into account and managed. This led to the failure in achieving the most of goals [9]. Also, an incentive to search for new solutions was as a result of the relatively low level of trust among citizens in the state institution. This is confirmed by 
recent international research showing that Russia is one of the countries with the lowest level of citizens' trust in government, which has even a tendency to further decrease [9].

The project office of Smart St. Petersburg was founded at ITMO University and headed by the governor of St. Petersburg in early 2018. Such a high status of the project office allowed initiating a series of research projects aimed at studying the problems of development towards becoming a Smart City. Among them were several ones dedicated to the study of the problem of trust. This increase in attention to the problems of trust and the expansion of its interpretation has been observed only recently. Gradually, it comes to the understanding that studying the trust of citizens solely on the safety aspects and technical reliability of the created IT systems, which has been practised in Russia so far, does not answer pressing questions. It also does not correspond to current trends and challenges.

The research questions of this study is "Which trust factors have the most significant impact on the citizens' and civil servants' intention to participate in smart city services" The study is conducted for Smart St. Petersburg services which limits its generalizability. The novels of the study described in this article are:

a) A significant expansion of the conceptualization of the terms "Smart City" and "Trust" in comparison with that previously practiced in Russia and in St. Petersburg (described in the Literature Review section);

b) Formulation of research hypotheses that have not been analysed in relation to the problems in the development of St. Petersburg and its solution which is not reflected in the regulatory documents so far (described in the Hypotheses Development section);

c) The applied methodology based on various sources of information (polls of citizens and government officials, regulations, official statistics, websites of civil initiatives and analysis of publications in social networks) that complement and doublecheck each other (described in the Research Methodology section).

Some of the most important, in our opinion, research results with their interpretations and discussions are given in the sections: Findings and Reflections, conclusion.

\section{$2 \quad$ Literature background}

\subsection{Trust and Trust in innovations}

The history of the theory of trust development within sociology began with authors such as Fukuyama [10], Sztompka [11], Luhman [12], Barber [13], Coleman [14], and Hardin R. [15]. These authors viewed trust as a critical element of social relations in modern society, which is essential for harmony and economic prosperity.

While trying to answer the question of trust in innovations, some researchers relied on the theory of diffusion of innovations by Rogers [16]. In this theory, the development of any new technology was considered as the result of a comparative assessment by the user of five main factors: comparative advantages when using this technology, its 
compatibility with previous technologies of the same type, the complexity of learning new skills, the ability to independently test the new technology and its visibility.

A simpler theory named that "technology acceptance model" (TAM) was proposed by Davis [17]. TAM described the intention to use new technology as a result of a rational correlation of the expected benefits of the technology with the expected difficulties in its development.

However, both of these theories exclude the social context within which technological innovations are adapted. Content is considered often as essential. The introduction of new technologies, especially information technologies has created a lot of new problems associated with trust in them. Two of the first researchers in the field of assessing the role of trust based on the theory of social construction of technology were MacKenzie and Vedzhkman [18]. Carter and Belanger [19] extend TAM and include trust was identified as the main factor contributing to the adaptation of information and communication technologies, expected benefits and expected ease of development.

The introduction of information technology in the public sector is often associated with the creation of electronic services and research in this area we consider relevant to our tasks. Analysing the problem of adapting to public electronic services, L. Carter and V. Weerakkody [20] clarified the concept of "trust", dividing it into trust in information and communication technologies and trust in authorities, who offer to use their services in electronic form.

Later, this concept was further elaborated by M. Horst, M. Kutshreuter and J.M. Gutteling. In their work, trust in the authorities was interpreted as the need of users to trust the ability of the authorities to manage the new service delivery system ("information management capacity"). Trust in the authorities was also defined as confidence in the technical reliability of the relevant infrastructure and its services [21].

Empirical studies have shown a direct correlation between the level of trust in government and the willingness to use its electronic services. In the above mentioned study by M. Horst and his co-authors on Dutch material, it was demonstrated that the higher the level of trust in the ability of authorities to provide services in an electronic form and the less the worry in the technical reliability of the electronic services system, the stronger the respondents express their intention to use such services [21]. In other words, trust in the authorities is a strong positive incentive that contributes to the adaptation of government electronic services.

The same conclusions were made by J. Lee, H.Yu. Kim and M.J. Ahn, who investigated the attitude of small and medium-sized entrepreneurs to e-government in South Korea [22]. They showed that a high level of trust is based on the personal experience of citizens and implies satisfaction with the quality of existing public services. Also, the Korean authors made the assumption that there is not only a direct, but also an inverse correlation between the level of satisfaction with traditional services and the readiness to use their electronic equivalent. Therefore, a high level of trust in the authorities can act not as an incentive, but as a barrier to the transition. In this case, with a high level of satisfaction with traditional services, citizens may not feel the need and might not be willing to take risks, moving to a new type of service.

On the contrary, with a low level of satisfaction with the work of state institutions, citizens may have hope that interacting with the authorities in electronic form, they will 
be able to avoid the unavoidable personal interactions. In the course of research in Korea, this assumption was not true as entrepreneurs considered the high quality of public services as a pledge that the authorities will be able to provide the same quality of work in electronic form. Therefore, their satisfaction with the quality of services increased their willingness to switch to the electronic format of interaction with officials and dissatisfaction dramatically reduced the estimated utility of such services. However, one should not discard this assumption completely.

\subsection{Smart City}

Before answering questions about various aspects of trust in the Smart City, we need to understand what the Smart City term means. It should be recognised that in world practice, there are many ways for describing the term and concept of a Smart City [23, 24]. For the purposes of our study, we have found some useful approaches proposed by several authors.

A higher impact on the formation of a Smart City image had a techno-centric approach, offering such a definition as "The vision of smart cities is the urban centre of the future, made safe, secure, environmentally green and efficient because all structures whether for power, water or transportation are designed, constructed, and maintained making use of advanced, integrated materials, sensors, electronics and networks which are interfaced with computerized systems" [25, p.5]. However, over time, more and more attention in the definition of smart cities is being paid to achieving the goals related to the well-being of the inhabitants and their leading role in shaping development policies: "The concept of Smart City (SC) as a means to enhance the life quality of citizen has been gaining increasing importance in the agendas of policymakers" [26, p.35]; A city "connecting the physical infrastructure, the IT infrastructure, the social infrastructure, and the business infrastructure to leverage the collective intelligence of the city" [27, p.361]; "A city well performing in a forward-looking way in economy, people, governance, mobility, environment, and living, built on the smart combination of endowments and activities of self-decisive, independent and aware citizens" [28, p.11].

Thus, in spite of the fact that even the Wikipedia gives us a techno-centric definition "A smart city is an urban area that uses different types of electronic Internet of things (IoT) sensors to collect data and then use this data to manage assets and resources efficiently" [29]. The same article states that these technologies are used to engage effectively with local people in local governance and decision by use of open innovation processes and e-participation. Thus, improving the collective intelligence of the city's institutions through e-governance, with emphasis placed on citizen participation and co-design [29]. The same point of view about the mandatory involvement of citizens to achieve success in the Smart cities' development was supported by Glasmeier and Christopherson [30] and Robinson [31]. 


\subsection{Trust in the Smart City' context}

A standard model conceptualizing a Smart City does not exist and each city must create its own original smart solutions depending on its unique requirements and for the best satisfaction of the interests of its citizens. Taking a citizen-centric approach implies the active participation of citizens in the construction of a Smart City that is possible only if there is trust between all interacting parties. Trust, in turn, is closely related to mutual understanding between the interacting parties regarding common goals and methods for achieving them. However, because smart cities are usually discussed as projects between technology providers, engineers, local authorities and universities, the ordinary people who vote for politicians, pay taxes, buy products, use public services and make businesses work are not even aware of the idea, let alone supportive of it [32]. Government leaders have an opportunity to build trust by communicating the strategic thinking and vision behind new programs that affect the long-term future of the community and which are often irreversible [33]. The success and sustainability of Smart City projects depend on the level of citizen trust in such initiatives and the ability of city governments and partners to ensure transparency and deliver valuable benefits and higher quality of life. As it said by BSI: "Transparency is important in order to build trust ... this means that the leadership of a Smart City programme should aim to publish all key vision and strategy documents, make names and contact details of programme leaders openly available and publish regular updates of the performance and delivery against the Smart City roadmap" [33, p.18].

In 2016, at the initiative of the IBM, a large-scale study of US government websites "Smart Trust Survey" was conducted and in the results, it was discovered that none of the city websites mentioned whether they have a Smart City strategy available (e.g., in the form of a strategy publication) to citizens and other stakeholders. This fact was regarded as a strong factor in reducing the level of trust [34]. In the same 2016, a study sponsored by the Institute of Engineering and Technology (IET) found a basic lack of awareness among the British public about what a Smart City does and its potential to improve citizens' quality of life. The danger is that smart cities may be developed without sufficient insight about what people actually want them to deliver [35]. Another study in the UK found the need to strengthen the activities of the government to enhance public engagement and user satisfaction towards smart services in order to realise the promises of such solutions [36]. Such citizen involvement can be implemented in many forms, but among the most promising is direct personal participation of a citizen in Smart City projects or taking part in the discussion of plans and strategies for its development [37, 38]. A trust-building framework for smart cities is multi-dimensional and should include the six major components [39]:

1. Clarifying Smart City commitment and strategy;

2. Delivering high quality of communication regarding planned projects, benefits and risks;

3. Ensuring civic engagement, participative democracy and co-creation;

4. Demonstrating the capability to innovate and deliver Smart City services;

5. Ensuring equitable solutions that offer value to all segments of society;

6. Providing guides and user-friendly apps to facilitate the adoption of new services. 


\section{$3 \quad$ Research Methodology}

The desire of the Administration of St. Petersburg to improve the performance of projects comprising of the Smart St. Petersburg program has set the Project Office to the task of studying the level of trust between stakeholders and its impact on the overall program's performance. Specifically, the focus is on the implementation of the research of cyber social trust in the context of the use and refusal of information technology funded by the Russian foundation for basic research.

Our study aims to answer the following research question: Which trust factors have the most significant impact on the citizens' and civil servants' intention to participate in the development and use the Smart St. Petersburg services?

As a result of reviewing several models of theoretical studies proposed by different authors, we chose the model proposed by Hisham Alsaghier [40]. This model has been slightly adapted to the Smart St.Petersburg context.

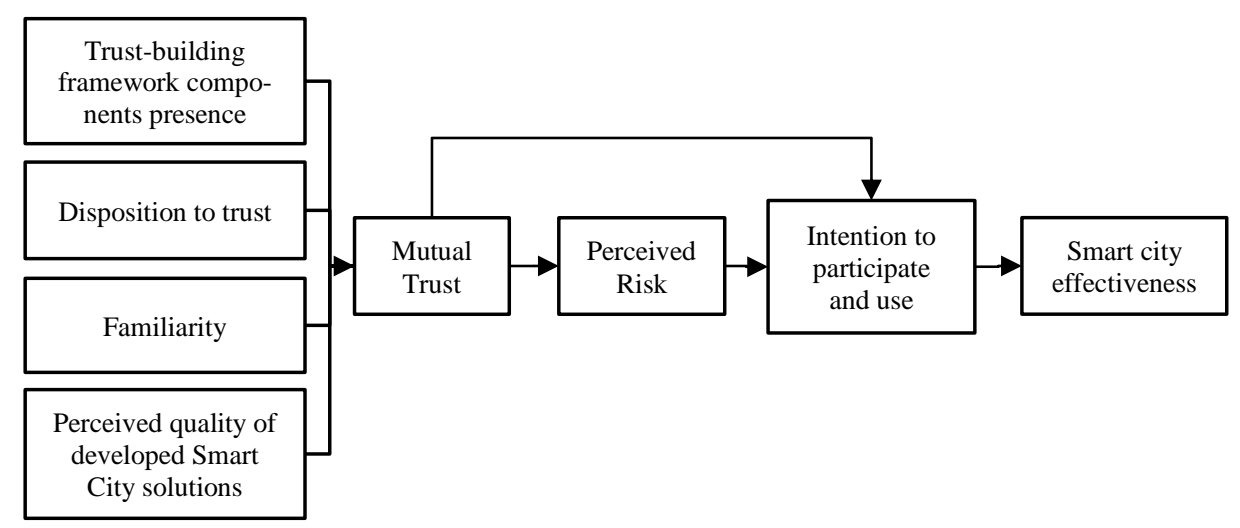

Fig. 1. Theoretical research model adapted after Hisham Alsaghier

Based on the chosen theoretical research, the study elaborated the following factors:

7. Trust-building framework components presence - are levels of presence of six major components of the trust-building framework described above.

8. Disposition to trust - this is a general state of citizens' and civil servants' trust in other people and society as a whole.

9. Familiarity is a personal attitude based on previous experience, studying and understanding who and why created it.

10. Mutual trust - the general level of trust between all interacting parties.

11. Perceived Risk - is the opinion of citizens and civil servants. Do they consider the benefits of using Smart City solutions to exceed the possible negative consequences of such use?

12. Intention to participate and use - is the opinion of citizens and civil servants. Do they wish to take an active part in the creation of Smart City solutions and use them?

13. Smart City effectiveness - What is the degree of achievement of the targeted benefits of Smart City? 
Disclaimer: Since the target benefits of the Smart St. Petersburg program are still under discussion, the present study limited itself to studying the influence of trust factors on citizens' and civil servants' intention to participate in the development and use the Smart St. Petersburg services.

During the research, qualitative and quantitative methods were used.

Quantitative research consisted of two studies:

1. A street survey of city residents was used to explore the end users' perceptions. The end-user group consists of average e-service users or potential users. Extensive questionnaires were prepared by researchers and volunteers collected the required answers during personal interviews with random passers-by in various parts of the city in December 2018. The total number of respondents and fully completed questionnaires was 600. Various social strata, level of education, IT-competence, income, sex were represented in proportion to their presence in the city.

2. Combination of a street survey and a survey of civil servants of various committees of the Administration of St. Petersburg conducted in March 2019. The main focus was on the experience of use and readiness to participate in the creation of new services of a Smart City. The total number of respondents and fully completed questionnaires was 600 . The ratio of residents and civil servants was 50/50. Different level of education, IT-competence, income, sex was represented in proportion to their presence in the city.

The qualitative research was organized in the form of collective discussion and attempted to interpret the evidence obtained from the surveys together with the discrepancies found between the planned and actual results of the projects during regular meetings of the project office members. The participating members of the Smart St. Petersburg project office had a direct influence on both the decision-making in the field of creating the Smart City's solutions and its implementation in the life of the city and utilization of expected benefits. The goal of the meetings was to understand which measures should be used by them to build citizens' trust in Smart City solutions.

The baseline data consists of respondents' answers in the form of a unified scale of 1 (disagree) - 5 (agree) with the proposed statements (A total of over 80 statements for evaluation in two surveys)

The list of variables used for the analysis is given in the Appendix.

\section{$4 \quad$ Findings}

The data was analysed using various statistical analysis. Figure 2 shows the averaged values of the data collected during the surveys for the selected variables. 


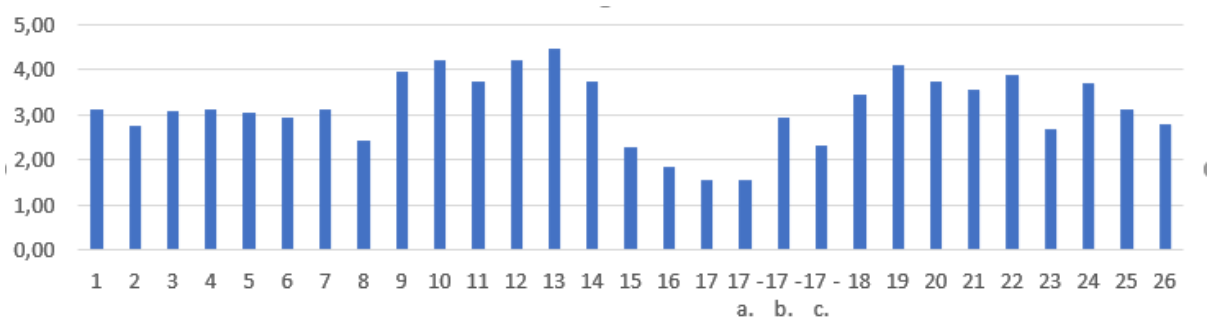

Fig. 2. Averaged values of the data collected during the surveys for the selected variables

(Variable numbers correspond to the list in the previous section).

There is a significant gap between the relatively high level of familiarity of the respondents with conventional information technologies and the low level of knowledge of the Smart City solutions.

Figure 3 allows us to see the differences in the observed trust-building framework components in different areas of city life. Observed significant differences will help us to make a subsequent correlation analysis to find the main dependencies between the variables under study.
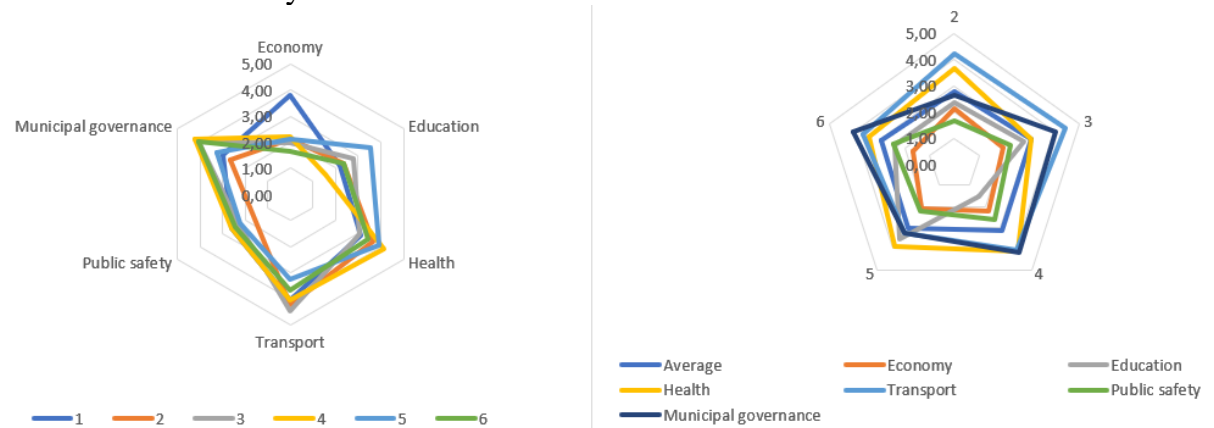

Fig. 3. Averaged values of the trust-building framework components by city life areas (Variable numbers correspond to the list in the previous section).

Since the main focus of our study was on finding trust factors (variables 1-20) with the greatest impact on the citizens' desire to participate and use smart St.Petersburg's solutions (variables 21-26), in Table 1 we present only part of the correlation analysis illustrating the sought dependencies.

Table 1. The results of the evaluation of the impact of selected variables on the intention of residents to participate in the development and use the Smart St. Petersburg services

(Variable numbers correspond to the list in the previous section).

\begin{tabular}{l|l|l|l|l|l|l|l|l|l|l|l|l|l|l|l|l|l|l|l|l|l|l}
1 & 2 & 3 & 4 & 5 & 6 & 7 & 8 & 9 & 10 & 11 & 12 & 13 & 14 & 15 & 16 & 17 & $17 \mathrm{a}$ & $17 \mathrm{~b}$ & $17 \mathrm{c}$ & 18 & 19 & 20
\end{tabular}

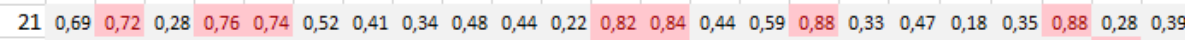

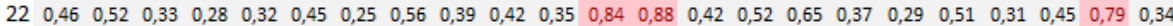
$\begin{array}{llllllllllllllllllllllll}23 & 0,53 & 0,28 & 0,68 & 0,32 & 0,34 & 0,39 & 0,26 & 0,62 & 0,28 & 0,32 & 0,38 & 0,88 & 0,92 & 0,38 & 0,64 & 0,69 & 0,38 & 0,32 & 0,28 & 0,55 & 0,59 & 0,35 & 0,88\end{array}$

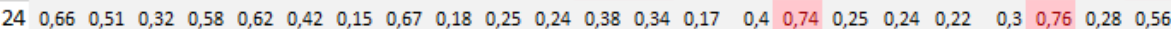

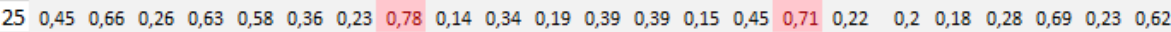

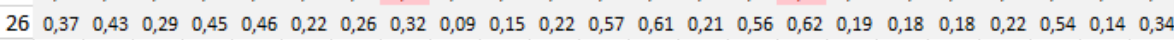

Table 1 shows clearly that the highest level of residents' desire to use the Smart City services depends on the following factors: 
1. Availability and relevance of smart city development plans, expected risks and benefits;

2. Quality of the created Smart City solutions and services;

3. Benefits obtained by various beneficiaries;

4. Level of citizens' familiarity with the PC, Internet and the Smart City's solutions from around the world;

These main dependencies were explained during expert councils as follows:

1. The publication of various strategic plans that are not being implemented is quite familiar to our environment. A more detailed description of the detailed planned actions, associated risks and expected benefits is unusual, attracts interest and inspires confidence;

2. Personal experience of using well or poorly created Smart City's solutions has a direct impact on trust / distrust of future ones;

3. The knowledge that various beneficiaries expect benefits that are meaningful to them gives rise to the hope that they will do their best to get them, which will lead to a belief in positive outcomes for all;

4. Since Russia is not a world leader in e-government and smart cities, it's understandable that trust in solutions has already been tested and led to positive results in other countries. Those familiar with such solutions are willing to create and use them to a much greater degree than those whose level of awareness is low.

Also, it is noted that he willingness to use feedback and e-participation tools depends primarily on the quality of these tools. The willingness to participate in the Smart City's strategy development discussion and its development plans co-creation highly depends on the willingness to trust municipal authorities and the familiarity with the Smart City's solutions from around the world.

The relatively weak influence of factors that were originally considered significant turned out to be a surprise for members of the Smart St. Petersburg's project office:

- The intensity of Smart City solutions promotion - Residents formed in the conditions of state propaganda and the promotion of false values have developed a certain immunity to attempts of state promotion of anything;

- Willingness to trust other people - This level was high on average, but had very slight variations, which did not allow detecting its effect on potentially dependent variables. It may be necessary to improve the methodology for evaluating this variable in further studies;

- Willingness to trust the Internet and service providers - Traditionally, St. Petersburg has a high level of confidence in the Internet and service providers with small fluctuations, which, just as in the previous case, does not allow to evaluate its impact;

- Level of familiarity with existing local Smart City solutions - Citizens with a very different level of familiarity with local solutions were included in the research sample. The low correlation of this variable with the desire of citizens to participate and create smart city solutions is difficult to explain and needs further research. 


\section{Conclusions}

In this study factors influencing trust in smart cities were investigated. The results of the study will help the city administration and the project office of the Smart St. Petersburg program to find the most optimal solutions to make the city more prosperous and comfortable for life. The study contributes to the understanding of trust factors in Smart City projects development. Four main factors were found, including Availability of published and current statements of commitment and strategy; Quality of the created Smart City solutions and services; benefits obtained by different beneficiaries, and level of citizens' familiarity with the PC, Internet and the Smart City's solutions from around the world.

The framework proposed could be of interest for GCIOs and IT- managers facing some issues of e-services and Smart City solutions effectiveness and expected benefits gaining. Among the main decisions developed based on the results of this study and which have already begun to be implemented are:

- Preparation of the order in the city's administration on the adaptation and publication of the strategy and work plans of the project of Smart St. Petersburg for their public discussion;

- Shifting the emphasis of creating Smart St. Petersburg from the digitization of the city to creating values for the main groups of its citizens based on the optimal choice of Smart City solutions from among the possible ones when drawing up plans for the next year.

Also, there is confidence in the city administration that the conducted research brings real benefits and such studies will continue.

Further planned research in this area will be focused on improving both the theoretical model used and on increasing the openness for citizens and the scientific community of discussion and interpretation of the results obtained. Also, the analysis of the obtained data will be more and more profound in further work.

\section{Acknowledgements}

The study was performed with financial support by the grant from the Russian Foundation for Basic Research (project №18-311-20001): "The research of cybersocial trust in the context of the use and refusal of information technology".

\section{References}

1. Baudouin, P.: Trust is key to the success of smart cities. IDATE DigiWorld (2016). https://en.idate.org/insight_smart_city_pb-2/, last accessed 2019/05/16.

2. Calderoni, L.: Distributed smart city services for urban ecosystems. Doctoral thesis, Dottorato di Ricerca in Informatica, University of Bologna. (2015). doi: 10.6092/unibo/amsdottorato/6858. 
3. Belanche, G., Casalo, L., Flavián, C., Schepers, J.: Trust transfer in the continued usage of public e-services. Information and Management, 51(6), 627-640 (2014). doi: 10.1016/j.im.2014.05.016.

4. Janssen, M,, Nripendra, P., Emma, L., Slade, Yogesh, K.: Trustworthiness of digital government services: deriving a comprehensive theory through interpretive structural modelling, Public Management Review, 20(5), 647-671 (2018), doi: 10.1080/14719037.2017.1305689.

5. Order of the Government of the Russian Federation No. 1632-p of 28.07. 2017 on the approval of the program "Digital Economy of the Russian Federation". Electronic document: Legal portal of the Russian Federation, http://pravo.gov.ru/proxy/ips/?docbody=\&link_id=0\&nd=102440918\&intelsearch $=\&$ firstDoc $=1$, last accessed 2019/05/16.

6. The strategy of economic and social development of St. Petersburg for the period up to 2030 of 13/05/2014, http://spbstrategy2030.ru/?page_id=102, last accessed 2019/05/16.

7. City priority program "Smart St. Petersburg" of 15.02.2017. https://www.petersburgsmartcity.ru/, last accessed 2019/05/16.

8. Basic and additional requirements for smart cities (Standard of "Smart Cities") of 04.03.2019, http://www.minstroyrf.ru/upload/iblock/74f/Standart.pdf, last accessed 2019/05/16.

9. Vransky, K.: Hoping for a "Smart City". New Izvestia 26.12.208, https://newizv.ru/article/tilda/26-12-2018/v-nadezhde-na-umnyy-gorod-pochemu-peterburg-proigryvaet-moskve-i-sochi, last accessed 2019/05/16.

10. Fukuyama, F.: Trust: Social Virtues and the Creation of Prosperity, London: Penguin Books (1996).

11. Sztompka, P.: Trust: A Sociological Theory, Social Forces, Volume 79, Issue 3, pp. 11871188 (2001), https://doi.org/10.1353/sof.2001.0022.

12. Luhman, N.: Trust and Power, New York: John Wiley \& Sons Ltd (1979),

13. Barber, B.: The logic and limits of trust, volume 96. Rutgers University Press New Brunswick, NJ (1983).

14. Coleman, J.: Foundations of Social Theory. Cambridge, MA: The Belknap Press Harvard University Press (1990).

15. Hardin, R.: Trusting Persons, Trusting Institutions, in R.J.Zechauser (ed), Strategy and Choice, Cambridge, MA: The MIT Press (1991).

16. Rogers, E.: Diffusion of Innovations. 5th ed. N.Y., The Free Press, pp. 512 (2003).

17. Davis, F.: Perceived Usefulness, Perceived Ease of Use, and User Acceptance of Information Technology // MIS Quarterly. V. 13. № 3. P. 319 - 339 (1989).

18. The Social Shaping of Technology / McKenzie D., Wajcman J. (eds.) 1st ed. L., Open Univ. Press. p. 462. (1985).

19. Carter, L.: The Utilization of E-Government Services: Citizen Trust, Innovation and Acceptance Factor. Information System Journal 15(1), 5 - 25 (2015).

20. Carter, L.: E-government Adoption: A Cultural Comparison. Information Systems Frontiers.. V.10, 473-482 (2008).

21. Horst, M.: Perceived Usefulness, Personal Experience, Risk Perception and Trust as Determinants of Adoption of E-Government Services in The Netherlands / Horst M., Kuttschreuter M., Gutteling J.M. // Computers in Human Behavior. V. 23. 1838 - 1852 (2007).

22. Lee, J.: The Willingness of E-Government Service Adoption by Business Users: The Role of Offline Service Quality and Trust in Technology. Government Information Quarterly. V. 28. $177-186(2011)$. 
23. Albino, V., Berardi, U., Dangelico, R.: Smart Cities: Definitions, Dimensions, Performance, and Initiatives. Journal of Urban Technology, Vol. 22, No. 1, $3-21$, (2015). http://dx.doi.org/10.1080/10630732.2014.942092.

24. Smart cities definitions. Electronic document: https://www.centreforcities.org/reader/smartcities/what-is-a-smart-city/1-smart-cities-definitions/, last accessed 2019/03/17.

25. Hall, R.: The vision of a smart city. Brookhaven National Laboratory, 2nd International Life Extension Workshop, Paris, France. https://www.osti.gov/servlets/purl/773961/, last accessed 2019/03/17.

26. Neirotti, P.; De Marco, A., Cagliano, A., Mangano, G., Scorrano, F.: Current trends in smart city initiatives: stylised facts. Department of Management and Production Engineering, Politecnico di Torino. Elsevier Journal of Cities, 38, pp. 25-36 (2014)

27. Harrison, C., Eckman, B., Hamilton, R., Hartswick, P., Kalagnanam, J., Paraszczak, J., Williams, P.: Foundations for smarter cities. IBM Journal of Research and Development, 54(4) 350-365. (2010). doi: 10.1147/JRD.2010.2048257.

28. Giffinger, R., Fertner, C., Kramar, H., Kalasek, R., Pichler-Milanović, N., Meijers, E.: Smart cities: Ranking of European medium-sized cities. Vienna, Austria: Centre of Regional Science (SRF), Vienna University of Technology. (2007). http://www.smart-cities.eu/download/smart_cities_final_report.pdf, last accessed 2019/03/17.

29. Wikipedia contributors: Smart City. Wikipedia, The Free Encyclopedia. https://en.wikipedia.org/wiki/Smart_city,

30. Glasmeier, A., Christopherson, S. Thinking about smart cities. Cambridge Journal of Regions, Economy and Society 2015, pp. 8, 3-12 (2015). doi:10.1093/cjres/rsu034.

31. Robinson, R. Why smart cities still aren't working for us after 20 Years. And how we can fix them (2016). https://theurbantechnologist.com/2016/02/01/why-smart-cities-still-arentworking-for-us-after-20-years-and-how-we-can-fix-them/, last accessed 2019/03/17.

32. Glasco, J.: Breakthrough! Innovation Management in Practice. CreateSpace Independent Publishing Platform (2013). ISBN-10: 1-45283-080-0.

33. British Standards Institution. Smart cities framework - Guide to establishing strategies for smart cities and communities. BSI Standards Publication, PAS 181:2014 (2014).

34. Ho, A., McCall, B.: Ten actions to implement big data initiatives: A study of 65 cities. IBM Center for the Business of Government (2016).

35. IET Future Cities: Smart cities - Time to involve the people? A report based on research commissioned by The Institution of Engineering and Technology (2016).

36. Peng, G., Nunes, M., Zheng, L.: Impacts of low citizen awareness and usage in smart city services: The case of London's smart parking system. Syst E-Bus Manage, (2016). doi:10.1007/s10257-016-0333-8.

37. Mader, I.: The new social contract: From representative to participative democracy (4.0). Excellence Institute. http://www.excellence-institute.at/en/the-new-social-contract-fromrepresentative-to-participative-democracy-4-0/, last accessed 2019/03/14.

38. Glasco, J.: Building Trust in Smart Cities: The Importance of Clarity, Communications and Civic Engagement. https://www.researchgate.net/publication/317870057/, last accessed 2019/03/14.

39. Hisham, A.: Conceptualising Citizen's Trust in e-Government: Application of Q Methodology. Electronic Journal of e-Government, http://www.ejeg.com/issue/download.html?idArticle $=148$, last accessed 2019/05/14 


\section{Appendix}

Trust-building framework components (According to Glasco J., by the economy, education, health, transport, public safety, municipal governance):

1. Availability of published and current statements of commitment and strategy;

2. Availability and relevance of Smart City development plans, expected risks and benefits;

3. Availability, convenience, performance of e-participation tools;

4. Quality of the created Smart City solutions;

5. Benefits obtained by various beneficiaries;

6. The intensity of Smart City solutions promotion.

\section{Disposition to trust}

7. Willingness to trust other people;

8. Willingness to trust municipal authorities;

9. Willingness to trust Russian Internet and service providers;

10. Willingness to trust foreign Internet and service providers;

11. Willingness to trust social network administrators

\section{Familiarity}

12. Level of familiarity with the PC;

13. Level of familiarity with the Internet;

14. Level of familiarity with traditional public services;

15. Level of familiarity with e-government services;

16. Level of familiarity with the solutions of Smart City from around the world;

17. The level of familiarity with the local Smart City solutions.

a. Services;

b. Feedback;

c. Participation tools;

Perceived quality of developed Smart City solutions

18. Quality of the Smart City services;

19. Quality of feedback tools;

20. Quality of e-participation tools;

\section{Intention to participate and use}

21. Willingness to use Smart City services;

22. Willingness to use feedback tools;

23. Willingness to use e-participation tools;

24. Willingness to participate in the Smart City's strategy development discussion;

25. Willingness to participate in the Smart City development plans co-creation;

26. Willingness to participate in the Smart City specific solutions creation. 